\title{
Integrated analysis of gene expression from carbon metabolism, proteome and metabolome, reveals altered primary metabolism in Eucalyptus grandis bark, in response to seasonal variation
}

Ilara Gabriela Frasson Budzinski ${ }^{1}$, David H. Moon ${ }^{1}$, Júlia Silva Morosini ${ }^{1}$, Pernilla Lindén², Juliano Bragatto ${ }^{1}$ Thomaz Moritz ${ }^{2}$ and Carlos Alberto Labate 1* $^{*}$

\begin{abstract}
Background: Seasonal variation is presumed to play an important role in the regulation of tree growth, especially for Eucalyptus grandis, a fast-growing tree. This variation may induce changes in the whole tree at transcriptional, protein and metabolite levels. Bark represents an important group of tissues that protect trees from desiccation and pathogen attack, and it has been identified as potential feedstock for lignocellulosic derived biofuels. Despite the growing interest, little is known about the molecular mechanisms that regulates bark metabolism, particularly in tropical countries.

Results: In this study we report the changes observed in the primary metabolism of E. grandis bark during two contrasting seasons in Brazil, summer (wet) and winter (dry), through the combination of transcripts (RT-qPCR), proteome (2-DE gels) and metabolome (GC-MS) analysis, in an integrated manner. Twenty-four genes, involved in carbon metabolism, were analyzed in the two seasons. Eleven were up-regulated in summer, three were up-regulated in winter and ten did not show statistical differences in the expression pattern. The proteomic analysis using 2-DE gels showed 77 proteins expressing differences in abundance, with 38 spots up-regulated in summer and 37 in winter. Different metabolites significantly accumulated during winter.

Conclusions: This study revealed a metabolic reconfiguration in the primary metabolism of E. grandis bark, triggered by seasonal variation. Transcripts and protein data suggests that during winter carbohydrate formation seems to be favored by tree metabolism. Glucose, fructose and sucrose accumulated at significant levels during the winter.
\end{abstract}

Keywords: Eucalyptus grandis, Metabolomics, Primary metabolism, Proteomics, RT-qPCR

\footnotetext{
* Correspondence: calabate@usp.br

'Laboratório Max Feffer de Genética de Plantas, Departamento de Genética,

Escola Superior de Agricultura Luiz de Queiroz, Universidade de São Paulo,

Piracicaba, SP 13418-900, Brasil

Full list of author information is available at the end of the article
} 


\section{Background}

Eucalyptus species are the most widely planted hardwood due to the quality of its wood. These fast-growing trees are cultivated under a range of different climates and can be destined to different industrial processes (e.g. pulp and paper, charcoal, fuel wood, and solid wood products). Most of the current Eucalyptus production in Brazil is cultivated in an area over 5.4 million hectares [1]. Given its fast growing rates and coppicing ability, eucalyptus has also been identified as a potential feedstock for biofuels [2]. Besides, bark is also a source of nutrients, carbon as well as being used to form a protective covering of soils in commercial plantations. Bark comprises all the tissues outside the vascular cambium and it includes primary and secondary phloem, cortex, first periderm, rhytidome and tissues formed by dilatation growth [3]. These tissues also protect woody plant organs and healing tissues from dehydration, solar irradiation and pathogens [4]. Bark formation is initiated by the process of cell division at the cambium, which produces xylem on the inner woody side and phloem, the primary bark tissue, on the exterior bark side. The phloem tissue contains phloem parenchyma, phloem fibers, companion cells and sieve cells [5]. Although tree development is regulated by seasonal periods, little is known about the underlying molecular processes related to growth, especially in the bark. Soler et al. [4] analyzed the seasonal variation in mRNA abundance in cork tissue from Quercus suber. They found transcripts for structural genes involved in suberin production accumulating in late spring; this accumulation was significantly correlated with temperature and relative humidity. The increased expression of genes involved in stress was also strongly correlated to temperature. Using the proteomic approach, Pagter et al. [6] observed distinct seasonal protein patterns in bark of Hydrangea macrophylla and Hydrangea paniculata during cold acclimation and de-acclimation.

In the present study, we investigated the metabolic response of $E$. grandis bark in two contrasting seasons: summer/wet and winter/dry, using RT-qPCR, proteomic and metabolomic analyses, with emphasis on carbon metabolism. Despite the importance of bark metabolism to the whole tree and its potential for biofuel production [7], to our knowledge this is the first molecular study showing changes in eucalyptus bark metabolism, in response to seasonal variation.

\section{Results and discussion}

\section{Seasonality influences mRNA expression in bark}

As a first step to understand the molecular mechanisms underlying the maintenance of primary metabolism in E. grandis bark during the summer and winter, the relative mRNA abundance of a set of 24 candidate genes (Additional file 1) involved in carbohydrate metabolism with emphasis in glycolysis, sucrose metabolism, ethanol fermentation, tricarboxylic acid cycle and carbon fixation were analyzed by RT-qPCR. Figure 1 shows the relative mRNA abundance of these genes during the contrasting seasons. Of these, 11 genes were up-regulated in summer (Fructose bisphosphate aldolase cytoplasmatic (FBAcyt), Pyruvate kinase $(P K)$, Phosphoenolpyruvate carboxylase (PEPC), ATP-dependent phosphofructokinase (PFK), Phosphoglucomutase (PGM), Sucrose synthase 3 (SuSy3), Pyruvate decarboxylase $(P D C)$, Isocitrate dehydrogenase $(I D H)$, Succinyl-CoA ligase $(S C L)$, Rubisco large subunit $(R b c L)$ and Ribose 5-phosphate isomerase $(R P I)$ ), three genes were up-regulated in winter (Phosphoglycerate mutase (PGAM), Sucrose synthase 1 (SuSy1) and Alcohol dehydrogenase 3 $(A D H 3))$ and 10 genes showed no statistically significant differences between seasons (Glucose 6-Phosphate isomerase $(G P I)$, Phosphoglycerate kinase $(P G K)$, Enolase $(E N O)$, Pyruvate dehydrogenase $(P D H)$, PPi-dependent phosphofructokinase (PFP), Alcohol dehydrogenase 2 (ADH2), NADP Malic enzyme (NADP-ME), Carbonic anhydrase $(C A)$, Rubisco small subunit $(R b c S)$ and Fructose bisphosphate aldolase chloroplast $(F B A c l)$ ).

Most of the genes involved in carbohydrate metabolism and glycolysis were up-regulated in summer (Fig. 1a), suggesting that during this season, primary metabolism is being required for the production of reducing power and ATP, necessary for the development and growth of the trees. During winter, the metabolic activity decreases and, as a consequence, trees reduce their growth rates, thus reducing their energy consumption. It is interesting to note that each SuSy analyzed showed a different expression pattern; SuSy1 was highly expressed in winter while SuSy3 were highly expressed in summer. Susy plays a crucial role in the sucrose metabolism. The enzyme catalyzes the reversible conversion of sucrose and UDP to UDP-glucose and fructose, but it also degrades sucrose [8]. Thus, each alternative transcript could be required for a different molecular function. Moreover, it has been proposed that there are two forms of Susy in higher plants [9], one is a soluble enzyme found in the cytoplasm (S-Susy) and the other is a membrane associate enzyme (P-Susy). Both forms are probably regulated by the phosphorylation status of the enzyme [10]. Further investigations are necessary to completely understand the mechanism that regulates Susy isoforms in eucalyptus bark.

The genes $A D H 3$ and $P D C$ involved in the fermentative metabolism showed statistically significant differences in expression (Fig. 1b). Curiously, each transcript was up-regulated in a different season. As we expected $A D H 3$ was up-regulated in summer, during the growing season. We also expected that $P D C$ was up-regulated in summer; however, it showed an opposite expression pattern. As a fast growing tree, eucalyptus requires high 


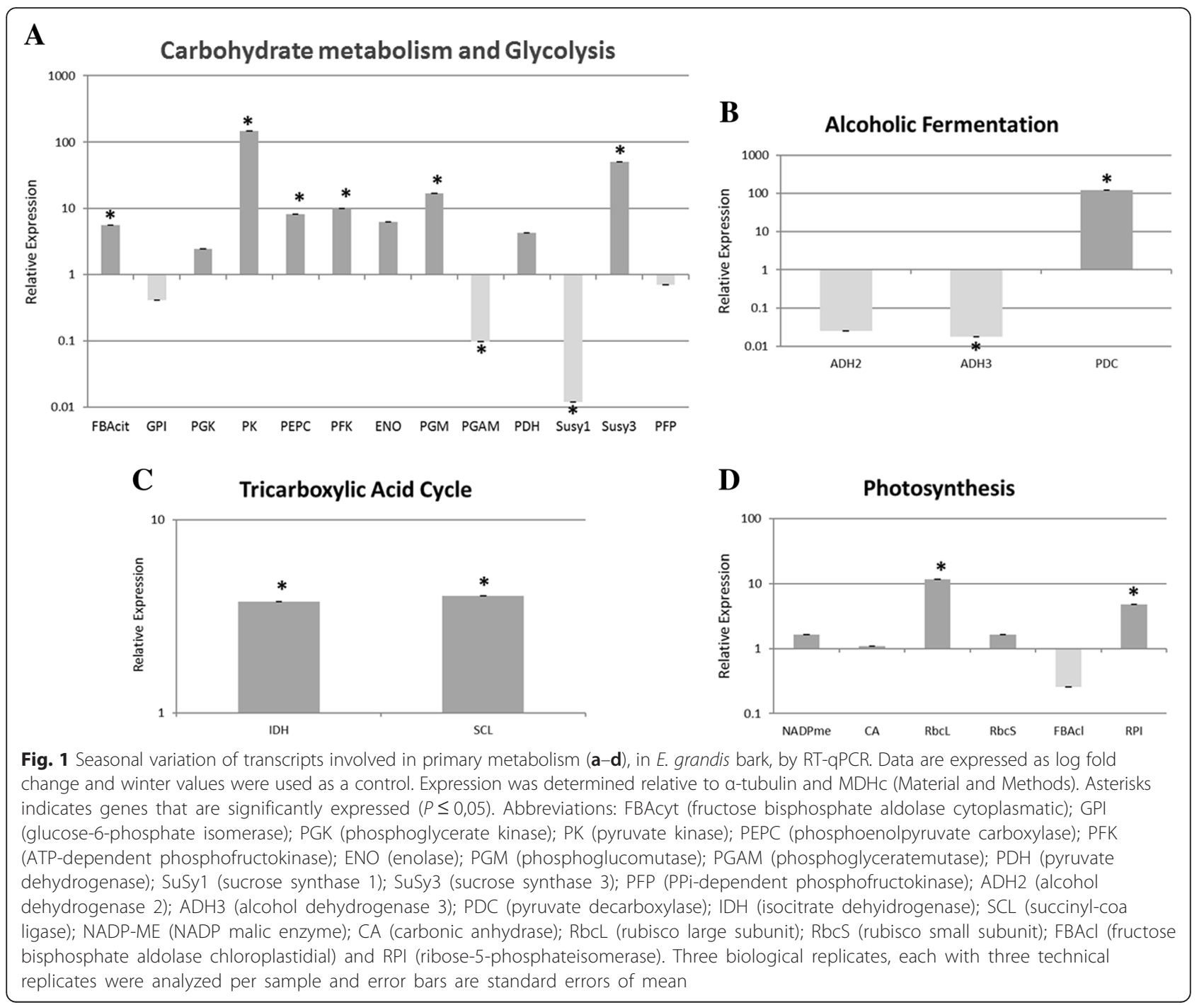

levels of ATP in summer to maintain this process. At the same time, the cambial and bark tissues are under hypoxic conditions due to anatomical barriers to gas exchange. Thus, respiration might shift from the aerobic to the ethanolic fermentation mode, as a means to maintain substrate-level for ATP production. This requires transcriptional activation of the essential genes of ethanolic fermentation, $P D C$ and $A D H$ [11]. Our data suggest that ethanolic fermentation is probably required in summer and winter, with the participation of different $P D C$ alternative transcripts. The regulatory role of $P D C$ in ethanolic fermentation has not yet been fully explained [12]. In Arabidopsis there are four genes encoding PDC and a microarray dataset related to low oxygen conditions, revealed that $P D C 1$ and $P D C 2$ were strongly up-regulated under low oxygen, whereas $P D C 3$ and PDC4 mRNA levels were not induced by anoxia, suggesting that these two genes were unlikely to play a role during anoxic stress [13].
Yang et al. [14] found one $A D H$ in the bark of Robinia pseudoacacia, however the authors did not discuss the transcript function. The study of the ethanolic fermentation process in trees started around the late 1980s [15-17] although until now little information is available and more research in this field is necessary.

$I D H$ and $S C L$ were the genes from TCA analyzed in our work, and both were up-regulated in summer (Fig. 1c). IDH is responsible to the oxidative decarboxylation of isocitrate to 2-oxoglutarate, the function of this enzyme has been associated with the maintenance of the 2-oxoglutarate level and the regulation on nitrogen assimilation [18]. SCL catalyzes the reversible interconversion of succinyl-CoA to succinate, characterization of the regulatory properties of this enzyme suggests that it may represent an adaptive mechanism in the attempt to maintain the rate of respiration under suboptimal condition $[19,20]$. Our results may suggest that in summer, the pyruvate produced via glycolysis is mainly sent to 
mitochondria, where it will be used by the TCA cycle, for energy production, instead of being used in the fermentative metabolism. It's important to mention that as described above, most of the transcripts analyzed in carbohydrate metabolism and glycolysis were also upregulated in summer, indicating that this pathway is working in the direction of pyruvate formation. Trees show higher metabolic activity in summer and during this period, active growth, glycolysis and the TCA cycle are fundamental to maintain high metabolic rate. Curiously, we observed that $P E P C$ was up-regulated in summer. The export of TCA cycle intermediates requires the importation of substrates that can generate both acetyl-CoA and oxaloacetate (OAA) [21]. If pyruvate is used as a unique substrate, export of TCA cycle intermediates, would reduce OAA regeneration and bring the TCA cycle to a halt. In such condition PEPC plays an important role in the anaplerotic fixation of $\mathrm{CO}_{2}$ and in the route to replenish TCA intermediates that are withdrawn from the pool [22, 23]. PEPC activity was reported as being more than ten times higher in stem of Fagus sylvatica than in leaves [23]. This high PEPC activity in stem could be explained by the anaplerotic roles of PEPC, common in C3 plants or, as in C4 metabolism, PEPC could be supplying malate for NADP-ME, which supplies $\mathrm{CO}_{2}$ for Rubisco by malate descarboxylating [23].

In trees several physiological process such as growth, respiration, the lack of stomata and the low permeability of stem peridermal layers to gaseous diffusion, result in a high internal $\mathrm{CO}_{2}$ concentration $\left(\left[\mathrm{CO}_{2}\right]\right)$ (range $<1$ to $26 \%$ ) and thus 500-800 times higher $\mathrm{CO}_{2}$ levels than in ordinary plant organs or ambient air [23, 24]. High $\mathrm{CO}_{2}$ concentrations effectively eliminate photorespiration, and enhance photosynthetic potential within branches and bark [25]. In accordance with this, we found in eucalyptus bark the accumulation of mRNAs related to $\mathrm{CO}_{2}$ fixation (Fig. 1). Among the analyzed transcripts only $R b c L$ and $R P I$ were differentially expressed, they were up-regulated in summer. The $N A D P-M E$ transcript was not differentially expressed between summer and winter. $R b c L$ was up-regulated in summer, the season in which trees have the highest respiration levels, leading to an increase in $\mathrm{CO}_{2}$ release in the interior of the stem. The RPI was also up-regulated in summer, it catalyzes the conversion of ribose 5-phosphate into ribulose 5-phosphate in the Calvin cycle and pentose phosphate pathways [26]. Considering the high $\mathrm{CO}_{2}$ availability inside the bark, our results suggests that $R b c L$ and $R P I$ are acting in the refixation of metabolically produced $\mathrm{CO}_{2}$. The stems of woody plants possess greenish tissues, that contain chlorophylls (the chlorenchymes) and are localized below the outer peridermal or rhytidomal layers. These tissues are able to use the stem internal $\mathrm{CO}_{2}$ and the light penetrating the rhytidome to fixate carbon [27], explaining the presence of rubisco in the bark. Thus, the high $\mathrm{CO}_{2}$ concentration and the low oxygen availability can explain the fact that $R b c L$ was differentially expressed and $\mathrm{RbcS}$ was not. Under such rich $\mathrm{CO}_{2}$ environment, inside the bark, maybe it is unnecessary for the plant to over produce $R b c S$ to promote $\mathrm{CO}_{2}$ fixation. Higher plant Rubisco is composed of eight large subunits coded for by a single gene, the $R b c L$, and eight small subunits coded for by the nuclear $R b c S$ multigene family [28]. The RbcL contain the catalytic site of the enzyme and is responsible for the carboxylase and oxygenase reactions but the $R b c S$, whose precise role in structure and function of Rubisco remains poorly understood, contributes to the differences in kinetic properties among Rubisco enzyme [29]. Transcripts of enzymes that participates in the photosystems I and II were also found in Robinia pseudoacacia bark [14].

\section{Proteomic Analysis of E. grandis bark during summer and winter}

The analysis of the protein profile from E. grandis bark was initially evaluated by $2-\mathrm{DE}$ gels, using strips with pH 3-10 in the first dimension (data not shown). The majority of the proteins spots observed were concentrated in the $\mathrm{pH}$ range 4-7 (data not shown). Based on this, we decided to analyze the protein profile, in triplicates, using the range of $\mathrm{pH} 4-7$ (Additional file 2: Figure S1). After image analysis, 445 and 424 protein spots were identified in summer and winter gels, respectively. From these, 125 spots were differentially expressed $(P \leq 0.05)$ between seasons and all of them were analyzed by mass spectrometry (Additional file 2: Figure S1). Among them 75 proteins spots (63\%) were successfully identified in the databank (Table 1); 38 were up-regulated in summer and 37 in winter. The remaining proteins were not further considered in the analysis as they did not match the search criteria.

\section{Functional classification of proteins differentially expressed found in bark}

The differentially expressed proteins between summer and winter were classified according to their biological processes into 5 categories (Fig. 2), similarly to the convention used by Rison et al. [30] and Carvalho et al. [31]. Proteins representing the functional categories "1-Metabolism and Energy" (36 \%), "5-Information Pathway" (33.3\%) and "2-Cellular Process" (20 \%) were the most abundant. Proteins from "1-Metabolism and Energy" category were distributed into five subcategories (Carbon Metabolism, Energy Metabolism, Energy Transfer/ATP-proton motive force, Nucleotide/Nucleoside Metabolism and Secondary Metabolism). The same was observed for the proteins from the categories "5-Information Pathways" 
Table 1 Identification of differentially expressed proteins spots from 2-DE gels

\begin{tabular}{|c|c|c|c|c|c|c|}
\hline Spot $n^{\circ}$ & Protein & Protein score & Coverage $\%$ & Sequence & $\mathrm{N}^{\circ}$ of Peptides & $\begin{array}{l}\text { Fold change } \\
\text { (summer/winter) }\end{array}$ \\
\hline & 1.1.1.2 C1 Metabolism & & & & & \\
\hline 21 & RuBisCO large subunit-binding & 410 & $11 \%$ & Egrandis_v1_0.005399 m & 6 & 0.4 \\
\hline 58 & $\begin{array}{l}\text { Ribulose bisphosphate carboxylase } \\
\text { large chain }\end{array}$ & 325 & $15 \%$ & RBL_ANTFO & 6 & 0.54 \\
\hline 59 & RuBisCO large subunit-binding & 263 & $13 \%$ & Egrandis_v1_0.005399 m & 4 & 0.74 \\
\hline 73 & Formate dehydrogenase & 1297 & $39 \%$ & Egrandis_v1_0.015998 m & 11 & 1.93 \\
\hline \multirow[t]{2}{*}{7} & Phosphoglycerate kinase & 3928 & $58 \%$ & Egrandis_v1_0.014782 m & 16 & 0.48 \\
\hline & 1.1.2 Energy Metabolism (Carbon) & & & & & \\
\hline 8 & Enolase & 122 & $5 \%$ & Egrandis_v1_0.021648 m & 1 & 0.46 \\
\hline 14 & Phosphoglycerate kinase & 1681 & $46 \%$ & Egrandis_v1_0.014782 m & 12 & 0.3 \\
\hline 51 & Phosphoglycerate kinase & 1452 & $32 \%$ & Egrandis_v1_0.014782 m & 8 & 0.4 \\
\hline 52 & Enolase & 128 & $3 \%$ & Egrandis_v1_0.010202 m & 5 & 3.77 \\
\hline 60 & Triosephosphate isomerase & 1092 & $45 \%$ & Egrandis_v1_0.020110 m & 9 & 0.56 \\
\hline 101 & Enolase & 1610 & $19 \%$ & ENO1_HEVBR & 6 & 1.33 \\
\hline \multirow[t]{2}{*}{114} & Enolase & 929 & $15 \%$ & ENO1_HEVBR & 4 & 0.43 \\
\hline & 1.1.3 Energy Transfer/Atp-Proton Motive Force & & & & & \\
\hline 3 & HSP20-like chaperones superfamily protein & 153 & $28 \%$ & Egrandis_v1_0.029820 m & 2 & 3.98 \\
\hline 25 & ATPase, V1 complex, subunit B & 964 & $27 \%$ & Egrandis_v1_0.010528 m & 10 & 0.35 \\
\hline 30 & ATP synthase alpha/beta family protein & 1664 & $51 \%$ & Egrandis_v1_0.007569 m & 17 & 0.36 \\
\hline 46 & Citrate synthase & 286 & $21 \%$ & Egrandis_v1_0.011280 m & 7 & 1.85 \\
\hline 91 & Citrate synthase & 523 & $18 \%$ & Egrandis_v1_0.011280 m & 5 & 1.56 \\
\hline \multirow[t]{2}{*}{97} & Malate dehydrogenase & 1094 & $30 \%$ & Egrandis_v1_0.018951 m & 6 & 0.62 \\
\hline & 1.2.1 Amino AcidMetabolism & & & & & \\
\hline \multirow[t]{2}{*}{71} & Phosphoglycerate dehydrogenase & 456 & $35 \%$ & Egrandis_v1_0.014972 m & 7 & 0.54 \\
\hline & $\begin{array}{l}\text { 1.2.3 Nucleotide/Nucleoside and Nucleotide } \\
\text { Sugar Metabolism }\end{array}$ & & & & & \\
\hline 2 & UDP-sugar pyrophosphorylase & 395 & $10 \%$ & Egrandis_v1_0.005961 m & 3 & 0.48 \\
\hline 41 & Adenosinekinase & 1965 & $45 \%$ & Egrandis_v1_0.018389 m & 10 & 1.96 \\
\hline 61 & UDP-glucose pyrophosphorylase & 89 & $6 \%$ & Egrandis_v1_0.011888 m & 2 & 2.08 \\
\hline 63 & UDP-glucose dehydrogenase & 554 & $22 \%$ & Egrandis_v1_0.010940 m & 6 & 1.9 \\
\hline 103 & UDP-glucose pyrophosphorylase & 621 & $32 \%$ & Egrandis_v1_0.011888 m & 7 & 0.49 \\
\hline \multirow[t]{2}{*}{106} & UDP-glucose pyrophosphorylase & 1187 & $41 \%$ & Egrandis_v1_0.011888 m & 13 & 0.46 \\
\hline & 1.2.8 Secondary Metabolism & & & & & \\
\hline 87 & NAD(P)-linked oxidoreductase & 445 & $24 \%$ & Egrandis_v1_0.019083 m & 5 & 2.05 \\
\hline \multirow[t]{2}{*}{96} & Phenylcoumaranbenzylicether reductase & 2400 & $76 \%$ & Egrandis_v1_0.020543 m & 15 & 0.45 \\
\hline & 2.1 Cell Processes & & & & & \\
\hline 78 & Vacuolar H + -ATPasecatalyticsubunit & 933 & $20 \%$ & Egrandis_v1_0.006156 m & 8 & 0.41 \\
\hline 70 & 14-3-3 protein & 654 & $26 \%$ & Egrandis_v1_0.043757 m & 6 & 0.45 \\
\hline \multirow[t]{2}{*}{123} & 14-3-3- protein & 1031 & $39 \%$ & Egrandis_v1_0.023614 m & 7 & 0.49 \\
\hline & 2.2.2 Protection Responses/Detoxification & & & & & \\
\hline 1 & Ascorbate peroxidase & 1788 & $41 \%$ & Egrandis_v1_0.024254 m & 6 & 4.71 \\
\hline 24 & Peroxidase & 209 & $9 \%$ & gi|242089639 & 2 & 1.9 \\
\hline 31 & Ascorbate peroxidase & 84 & $7 \%$ & Egrandis_v1_0.024254 m & 1 & 0.64 \\
\hline 33 & Ascorbate peroxidase & 1406 & $41 \%$ & Egrandis_v1_0.024164 m & 6 & 0.49 \\
\hline
\end{tabular}


Table 1 Identification of differentially expressed proteins spots from 2-DE gels (Continued)

\begin{tabular}{|c|c|c|c|c|c|c|}
\hline 45 & Ascorbateperoxidase & 121 & $10 \%$ & Egrandis_v1_0.024164 m & 1 & 1.93 \\
\hline 47 & Glutathioneperoxidase & 75 & $8 \%$ & Egrandis_v1_0.024172 m & 2 & 4.22 \\
\hline 69 & Glutathione S-transferase, C-terminal-like & 157 & $8 \%$ & Egrandis_v1_0.022631 m & 2 & 0.52 \\
\hline 74 & Ascorbateperoxidase & 1624 & $57 \%$ & Egrandis_v1_0.024217 m & 6 & 4.11 \\
\hline 79 & Ascorbateperoxidase & 1447 & $51 \%$ & Egrandis_v1_0.024254 m & 7 & 3.28 \\
\hline 99 & Ascorbateperoxidase & 200 & $14 \%$ & Egrandis_v1_0.024254 m & 2 & 2.32 \\
\hline \multirow[t]{2}{*}{107} & Copper/zinc-superoxidedismutase & 296 & $19 \%$ & Egrandis_v1_0.029096 m & 2 & 1.42 \\
\hline & 2.2.3.2 Abiotic & & & & & \\
\hline \multirow[t]{2}{*}{90} & Late embryogenesisabundantprotein & 1384 & $43 \%$ & Egrandis_v1_0.020038 m & 13 & 0.55 \\
\hline & 4.1.2.4 LigninMetabolism & & & & & \\
\hline 105 & Caffeicacid 3-O-methyltransferase & 383 & $31 \%$ & COMT1_EUCGU & 7 & 0.49 \\
\hline \multirow[t]{2}{*}{124} & Caffeicacid 3-O-methyltransferase & 328 & $3 \%$ & Egrandis_v1_0.003388 m & 6 & 0.57 \\
\hline & 4.1.2.5 Expansins, Xetand Extensin & & & & & \\
\hline 54 & Major Latex protein MLP-like & 1055 & $50 \%$ & Egrandis_v1_0.029781 m & 6 & 0.71 \\
\hline \multirow[t]{2}{*}{95} & Major Latex protein (MLP-like) & 792 & $55 \%$ & Egrandis_v1_0.029781 m & 6 & 0.83 \\
\hline & 4.3 Cytoskeleton & & & & & \\
\hline 17 & Beta-tubulin & 267 & $13 \%$ & Egrandis_v1_0.012369 m & 4 & 0.42 \\
\hline 102 & Beta-tubulin & 1533 & $27 \%$ & Egrandis_v1_0.012451 m & 11 & 0.46 \\
\hline \multirow[t]{2}{*}{111} & Beta-tubulin & 2034 & $34 \%$ & Egrandis_v1_0.012369 m & 15 & 0.79 \\
\hline & 5.2 Rna Related & & & & & \\
\hline \multirow[t]{2}{*}{44} & Glycine-rich RNA-binding protein & 283 & $21 \%$ & Egrandis_v1_0.020038 m & 4 & 0.36 \\
\hline & 5.3.3 Translation Related & & & & & \\
\hline 66 & Eukaryoticinitiationfactor & 381 & $9 \%$ & Egrandis_v1_0.014208 m & 3 & 2.56 \\
\hline 75 & Elongationfactor 1 beta & 684 & $14 \%$ & Egrandis_v1_0.021389 m & 3 & 0.34 \\
\hline \multirow[t]{2}{*}{84} & Eukaryoticinitiationfactor & 1471 & $41 \%$ & Egrandis_v1_0.014208 m & 13 & 1.83 \\
\hline & 5.3.5 Protein Folding/Chaperoning & & & & & \\
\hline 4 & Heatshockproteins & 565 & $28 \%$ & Egrandis_v1_0.021389 m & 5 & 1.58 \\
\hline 11 & Heatshockprotein & 2052 & $28 \%$ & Egrandis_v1_0.044829 m & 15 & 2.53 \\
\hline 13 & Heatshockprotein & 230 & $13 \%$ & Egrandis_v1_0.027871 m & 2 & 0.32 \\
\hline 40 & Heat shock cognate $70 \mathrm{kDa}$ protein & 1888 & $31 \%$ & Egrandis_v1_0.003388 m & 18 & 2.72 \\
\hline 57 & Heatshockproteinmitochondrial & 385 & $21 \%$ & Egrandis_v1_0.026204 m & 3 & 1.89 \\
\hline 62 & Heatshockprotein (HSP20) & 1331 & $50 \%$ & Egrandis_v1_0.045806 m & 9 & 2.99 \\
\hline 67 & Heatshockprotein & 157 & $15 \%$ & Egrandis_v1_0.029182 m & 2 & 4.11 \\
\hline 76 & Heatshockprotein (Hsp20) & 1589 & $26 \%$ & Egrandis_v1_0.021389 m & 7 & 1.52 \\
\hline 82 & Heatshock 70 kDaprotein & 3155 & $44 \%$ & Egrandis_v1_0.005502 m & 23 & 3.84 \\
\hline 94 & Heatshockprotein & 810 & $34 \%$ & Egrandis_v1_0.029182 m & 5 & 1.54 \\
\hline 98 & Heatshockprotein (HSP20) & 363 & $23 \%$ & Egrandis_v1_0.026663 m & 4 & 1.8 \\
\hline 104 & Heatshockprotein & 383 & $18 \%$ & Egrandis_v1_0.026663 m & 5 & 1.99 \\
\hline 112 & Heatshockprotein & 2682 & $47 \%$ & Egrandis_v1_0.025526 m & 9 & 0.53 \\
\hline 118 & Heatshockcognate 70 kDa & 1292 & $24 \%$ & Egrandis_v1_0.003884 m & 14 & 0.53 \\
\hline 120 & Heatshockprotein & 1010 & $22 \%$ & Egrandis_v1_0.044829 m & 11 & 1.84 \\
\hline \multirow[t]{2}{*}{125} & Heat shock 70 kDa protein, mitochondrial & 1413 & $29 \%$ & Egrandis_v1_0.004853 m & 13 & 1.66 \\
\hline & 5.3.6 Protein Cleavage and Turnover & & & & & \\
\hline 42 & Proteasomalregulatoryprotein & 187 & $14 \%$ & Egrandis_v1_0.018412 m & 4 & 1.97 \\
\hline
\end{tabular}


Table 1 Identification of differentially expressed proteins spots from 2-DE gels (Continued)

\begin{tabular}{|c|c|c|c|c|c|c|}
\hline 55 & Proteasomesubunit beta type & 1215 & $34 \%$ & Egrandis_v1_0.021324 m & 7 & 1.78 \\
\hline \multirow[t]{2}{*}{68} & $\begin{array}{l}26 S \text { proteasome non-ATPase } \\
\text { regulatory particle }\end{array}$ & 533 & $28 \%$ & Egrandis_v1_0.023175 m & 4 & 0.63 \\
\hline & 6.2 Putative Protein & & & & & \\
\hline 116 & $\begin{array}{l}\text { NAD(P)-binding Rossmann-fold } \\
\text { superfamily protein }\end{array}$ & 386 & $21 \%$ & Egrandis_v1_0.018330 m & 6 & 0.72 \\
\hline
\end{tabular}

(subcategories Translation Related, Protein Folding/ Chaperoning and Protein Turnover") and "2-Cellular Process" (Signal Transduction and Response Proteins and detoxification).

\section{Proteins identified related to the primary metabolism}

Surprisingly we found only few proteins differentially expressed acting in primary metabolism. This result can be due to limitations of 2-DE gels technique or by the fact that only a reduced number of proteins related to primary metabolism changed in abundance between the two seasons. We found different proteins acting in carbohydrate metabolism, cell wall biosynthesis, glycolysis and TCA: UDP-glucose pyrophosphorylase (UGPase), UDP-glucose dehydrogenase (UGDH), phosphoglycerate kinase (three probable isoforms), triosephosphate isomerase, enolase (four probable isoforms), citrate synthase (two probable isoform) and malate dehydrogenase, all of them belong to different subcategories from the category "1. Metabolism and Energy".

Four probable isoforms of UGPase were found, showing different expression patterns. Three of them were up-regulated in winter and the last one was up-regulated in summer, indicating temporal expression regulation. UGPase is a key enzyme in sucrose metabolism that catalyzes the reversible production of glucose-1-phosphate and UTP to UDP-glucose and pyrophosphate, depending on the metabolic status of the tissue. In photosynthetic tissues UGPase converts glucose-1-phosphate to UDPglucose, which can be utilized for sucrose synthesis, or cell wall polysaccharides [32]. In non-photosynthetic sink tissues, UGPase is linked to sucrose degradation pathways by converting UDP-glucose produced by sucrose synthase to glucose-1-phosphate [33]. UGDH was up-regulated in winter and converts UDP-glucose to UDP-glucuronate, which is a precursor of hemicellulose and pectin. In woody tissues, the role of UGPase and UGP is poorly understood. Two UGDH genes mainly expressed in roots, stem and bark of 6-month-old $E$. grandis were cloned [34].

We found tree probable isoforms of phosphoglycerate kinase and four possible isoforms of triosephosphate isomerase, all of them up-regulated in winter. Two enolases were also up-regulated in winter and two were up-regulated in summer. Changes in abundance of proteins related to carbohydrate and energy metabolism during cold acclimation were observed in the Hydrangea paniculata bark [6]. In the subcategory "Carbon Metabolism" we found tree RbcL isoforms, all of them upregulated during winter. The $\mathrm{RbcS}$ was not found in our work, it is possible that RbcS was not detected as a differentially expressed spot. To our knowledge there are no data in literature related to the rubisco subunits expression pattern (transcripts and proteins) in trees bark. In the E. grandis cambial zone of trees with different ages, it has been demonstrated the presence of RbcL, by immunoblotting, the $\mathrm{RbcS}$ subunit was only detected in the leaf control [35]. Proteins related to carbon fixation were found in the bark of Prunus persica [36] and Picea sitchensis [37]. The protein profile of RbcL

Proteins Classification: Biological Process

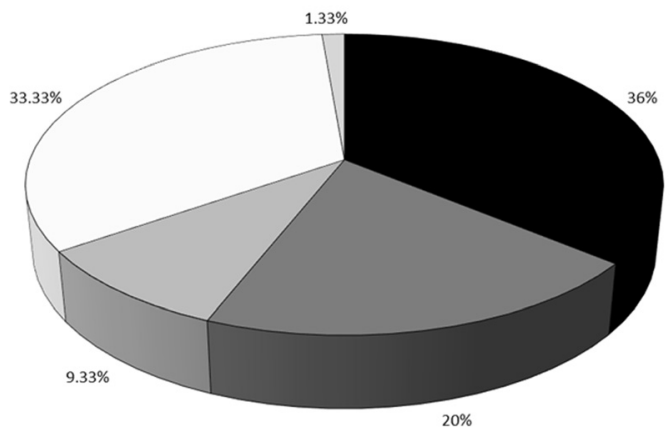

- 1. Metabolism and Energy

$\square 2$. Cellular Process

$\square 4$. Structure and Organization

$\square 5$. Information Pathways

口6. Miscelaneous

Fig. 2 Categorization of differentially expressed proteins in E. grandis bark in two contrasting seasons 
observed in our work was the opposite of the transcriptional pattern that we found, as the transcript was up-regulated in summer. The discrepancy between transcriptomic and proteomic data is widely discussed in the literature and probably indicates the occurrence of post-transcriptional and/or post-translational modifications [38-40].

\section{Proteins identified related to other biological pathways}

Proteomics provides the identification of a set of proteins expressed at a specific time, tissue or condition. Thus, we identified a diverse range of proteins involved in other biological process, besides primary metabolism. The proteins implicated in Protein folding/Chaperoning were the most abundant, among them 17 heat shock (HSP) were found and two were up-regulated in winter. Some HSPs are molecular chaperones that regulate the folding, localization, accumulation, and degradation of protein [41]. Thus HSPs play a crucial role in protecting plants against multiple environmental stresses by reestablishing normal protein conformation and homeostasis. Other proteins related to stress were found, such as: one late embryogenic protein (LEA), seven ascorbate peroxidases (APX) and two 14-3-3 proteins. LEA protein was up-regulated in winter; this protein is found in plant seeds and also in vegetative tissues under stress conditions such as cold, drought, or high salinity [42]. Among the seven APX identified, five were up-regulated in summer and two in winter. APX expression is induced in response to different forms of stress that results in the accumulation of reactive oxygen species (ROS) [43]. 14-3-3 proteins were also found. These are phosphoserine-binding proteins that regulate the activities of a wide array of targets via direct protein-protein interactions. In plants
14-3-3 regulates the plasma membrane $\mathrm{H}^{+}$-ATPase and enzymes of carbon and nitrogen metabolism [44]. Three translation-related proteins were identified, two initiation factors (up regulated in summer) and one elongation factor (up regulated in winter). Two caffeic acid o-methyltransferase (COMT) were up regulated in winter. COMT is one of the most important enzymes controlling lignin monomers production in plant cell wall synthesis.

\section{Soluble sugars in Bark}

Trees store a large amount of carbohydrates in parenchymatous tissues of their wood and bark. These stored carbohydrates can be required to meet the carbon needs for tree maintenance and growth when the current level of photosynthesis is not enough [45]. To confirm differences in carbohydrate storage between summer and winter we measured the soluble sugars from the summer and winter bark samples. A significant increase $(P \leq 0.05)$ in glucose, fructose and sucrose as well as in total soluble sugar content was observed in winter bark's (Fig. 3). In accordance with the literature our results indicate sugar accumulation during winter, the season in which trees show a reduction in growth (tropical regions) or even dormancy (temperate regions). During the summer season, the water availability is higher and eucalyptus has a higher growth rate. Thus, the consumption of carbohydrates stored in the bark is necessary, in order to maintain the high metabolic rate. In Cornus sericea $L$. glucose, fructose, sucrose and raffinose were the soluble sugars predominant in both, bark and wood tissues in the winter. In the early spring, the soluble sugar concentration decreased and the concentration of starch increased. Soluble sugars increased in the fall and reached a maximum

\section{Bark Soluble Sugars \%}

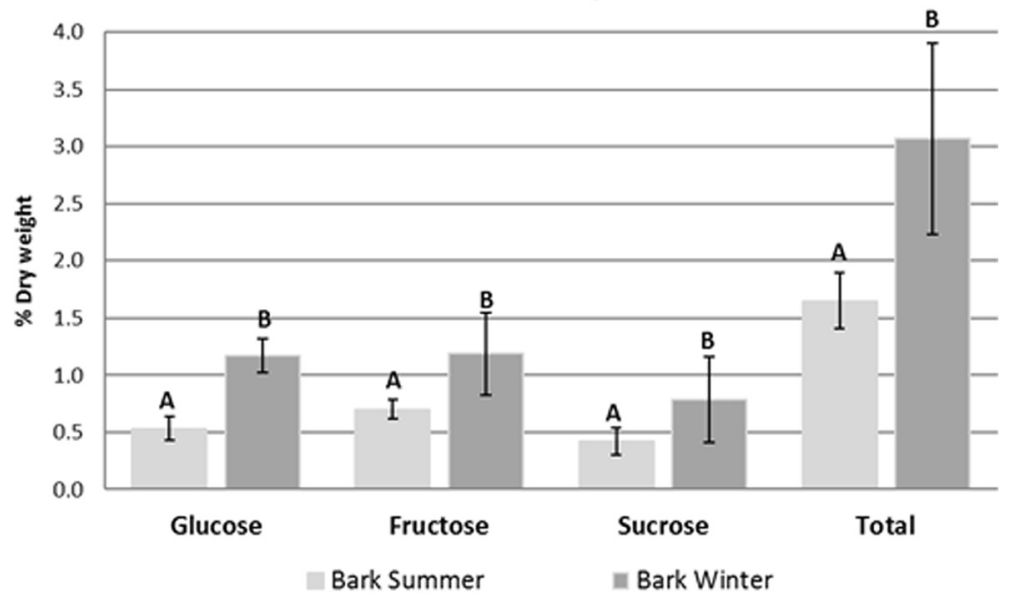

Fig. 3 Soluble sugar content of E. grandis bark during summer and winter. Soluble sugars were quantified by HPLC (Material and Methods). Three biological replicates with three technical replicates were performed for each season. Bars with same letter are not significantly different, based on Tukey's test $(P \leq 0.05)$. Error bars are standard errors of mean 
in mid-winter [46]. Higher concentration of soluble sugars was observed in the bark of Eucalyptus globulus submitted to water deficit [47]. Carbon investment in storage of carbohydrates may provide safety margins to allow trees to maintain hydraulic transport and metabolism during episodes of stress such as drought and insect attacks [48]. We believed that in our work glucose, fructose and sucrose might be accumulated during winter in response to diminished water availability instead of low temperatures. Thus, differences in precipitation between summer and winter, could be implicating in metabolic changes related to carbon allocation. Another point to be considered is the soluble sugar accumulation in response to low temperatures, as a mechanism of cold acclimation $[6,49]$ specially in trees from temperate regions. Travert et al. [50] exposed two genotypes of Eucalyptus cell-suspension cultures to low temperatures. The resistant cells (hybrid Eucalyptus gunnii $\mathrm{x}$ Eucalyptus globules) accumulated soluble sugars, in particular sucrose and fructose. In contrast the frost-sensitive cells (hybrid Eucalyptus cypellocarpa $\mathrm{x}$ Eucalyptus globules) did not accumulate soluble sugars in response to the same treatment. The authors correlated these data to the potential involvement of several carbohydrates (glucose, fructose, sucrose, raffinose and manitol) for improving freezing tolerance in Eucalyptus cells as well as the cryoprotection by sugars during cold acclimation.

\section{Metabolic profiling during seasonal variation}

Metabolic profiling was performed by GC-MS to identify changes in the primary metabolites resulting from seasonal variation. In total, 32 metabolites were identified in E. grandis bark. All metabolites were classified into five categories and the most representative were organic acids (28\%), sugars (21\%), fatty acids (18\%) and amino acids (9\%) (Additional file 1). A PLS-DA (partial least square discriminant analysis) derived scores plot (Fig. 4) showed a statistically significant separation of these two groups. The two PLS components accounted for $64.2 \%$ of the total variance. Our PLS-DA model comparing summer and winter barks had $R^{2}$ and $Q^{2}$ values of 0.95 and 0.91 , respectively. To identify the variables that had the most significant contribution in discriminating between metabolite profiles of summer and winter samples, we considered the variable importance in the projection (VIP) values higher than 1.0 combined with $p$-value less than 0.05. Based on it, we found eight metabolites differentially abundant between the summer and winter groups (Table 2). The organic acids highly abundant in bark during winter were shikimate and dehydroascorbic acid. Shikimate is an intermediate in the shikimic pathway, which links the carbohydrate metabolism to biosynthesis of aromatic compounds [51]. Dehydroascorbic acid is an oxidized form of the important antioxidant vitamin C [52].

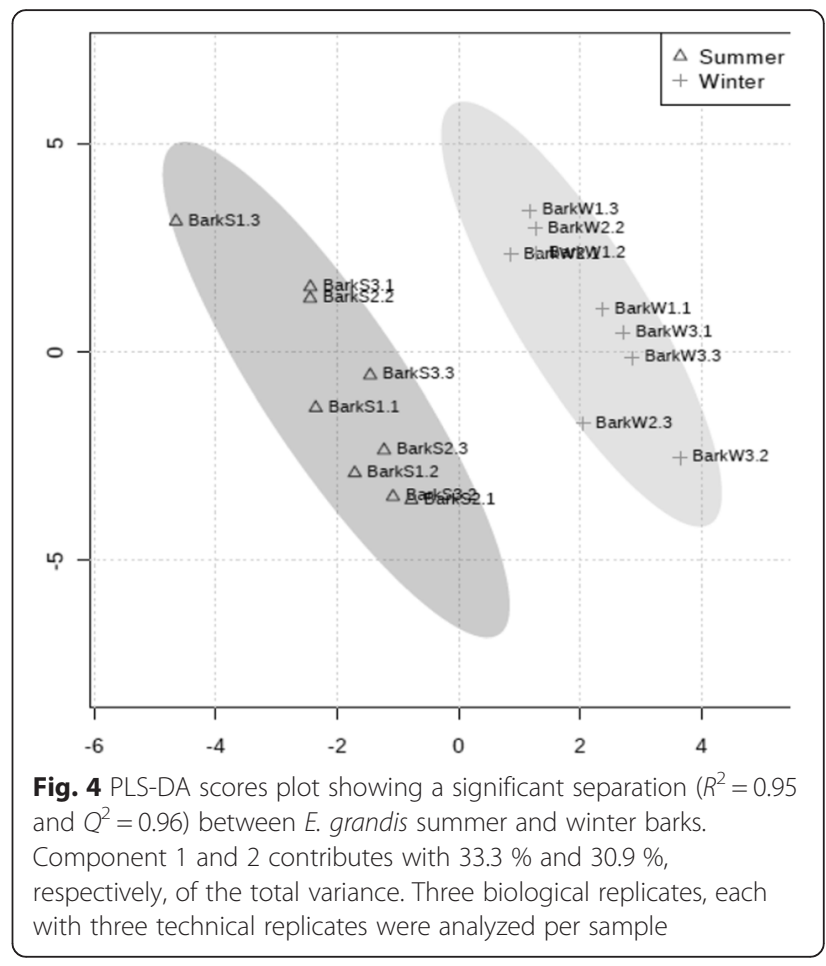

The flavonoid taxifolin and the sugar substitute erythritol were also highly abundant in winter. Malate, galactinol, gluconate and fumarate were the metabolites highly abundant during summer. Malate and fumarate are important intermediates in the TCA. In some C3 plants they can be accumulated during the day, decreasing during the night, suggesting that they function as transient carbon storage molecules [53]. In C3 plants, photosynthetic cells surrounding the vascular system are supplied with malate or $\mathrm{CO}_{2}$ from the xylem vessels. Thus, malate could be decarboxylated by these cells bordering the vascular system and the $\mathrm{CO}_{2}$ could be used in photosynthesis to produce carbohydrates [54]. Although soluble sugars (sucrose, glucose and fructose) accumulated in winter, galactinol was highly abundant during summer. It participates in the raffinose biosynthesis and both of them act protecting cellular membranes from abiotic stresses [55].

Table 2 Metabolites differentially abundant in bark

\begin{tabular}{lllll}
\hline Metabollite & Class & VIP & p.value & $\uparrow a b u n d a n t$ \\
\hline Erythritol & Sugar Alcohol & 2.85 & $5.40 \mathrm{E}-08$ & winter \\
Shikimate & Organic acid & 1.96 & $2.50 \mathrm{E}-05$ & winter \\
Malate & Organic acid & 1.9 & $4.90 \mathrm{E}-05$ & summer \\
Galactinol & Sugar & 1.52 & $3.50 \mathrm{E}-04$ & summer \\
Gluconate & Sugar & 1.29 & $1.60 \mathrm{E}-02$ & summer \\
Dehydroascorbic acid & Organic acid & 1.25 & $8.50 \mathrm{E}-03$ & winter \\
Fumarate & Organic acid & 1.14 & $1.70 \mathrm{E}-02$ & summer \\
Taxifolin & Flavonoid & 1.01 & $3.30 \mathrm{E}-02$ & winter \\
\hline
\end{tabular}




\section{Integrated analyses of E. grandis bark in response to seasonal variations}

Bark plays a fundamental role in transporting assimilated carbon to sink tissues where it can be used for growth and/or storage [56]. To obtain a more holistic view about the dynamic changes occurring in $E$. grandis bark metabolism due to seasonal variation, all the information generated in our work was grouped (Fig. 5). Our data demonstrate differences in carbon partitioning between summer and winter samples. At the transcriptional and metabolic level carbohydrate formation seems to be favored in winter and some proteins related to this pathway were also up-regulated in this season. During winter, the dry season, tree growth diminishes and, as a consequence, lower levels of carbon skeletons are required to promote cell wall growth and enlargement, contributing to sugar accumulation. Besides, in opposite to what happens in trees, from temperate regions, we do not believe that carbohydrates accumulate in
E. grandis bark, in response to cold acclimation/ freezing tolerance. We believe that this is due to lower water availability.

We did not find proteins related to ethanolic fermentation, probably due to limitations in 2D-gels, on the other hand we found differential expression for $A D H$ and $P D C$ transcripts. $A D H 3$ was up-regulated in summer and $P D C$ was up-regulated in winter. Although we did not find any metabolite directly related to carbon fixation, transcripts and proteins acting in Calvin-Benson Cycle were identified, especially RbcL, strongly suggesting that carbon fixation is occurring in bark.

\section{Conclusions}

Studies about the metabolism of bark trees are scarce and the effect of seasonal variation is also poorly understood. Given the importance of Eucalyptus, especially in Brazil, for different industrial applications, it is important to comprehend how seasonal variations affect the whole tree and tissues. Our results strongly suggest a

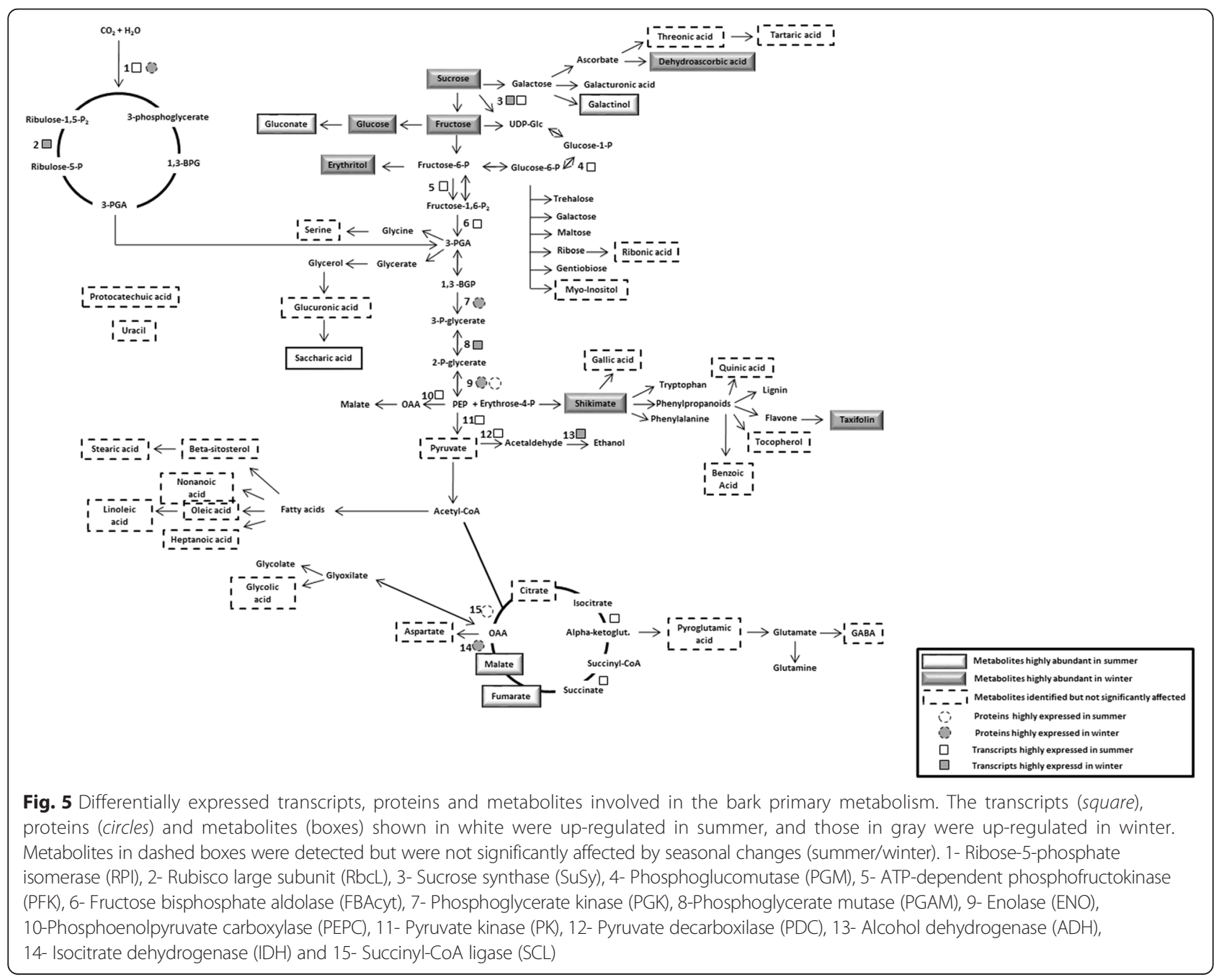


metabolic reconfiguration triggered by the shift between summer and winter periods, as we found significant differences in all levels investigated (transcripts, proteins and metabolites). During summer, when trees are fast growing, energy compounds are necessary to support glycolysis and mitochondrial electron transport chain. However, the high respiration rates associated with anatomical barriers generate a hypoxic environment inside the bark. Thus, ethanolic fermentation is an important pathway regenerating $\mathrm{NAD}^{+}$to the maintenance of glycolysis and plant metabolism. It is known that bark is a storage tissue and that during winter tree growth diminished. In winter, soluble sugars accumulate probably because of the diminished water available in tropical regions, and not because of lower temperatures (cold acclimation) as observed in temperate trees. An interesting data we observed was the identification of RbcL transcripts and proteins in bark. This study provides important data to understand seasonal variation in Eucalyptus bark. Future studies are necessary to identify which isoforms are involved in ethanolic fermentation and carbohydrate metabolism and also to clarify the precise function of RbcL in bark.

\section{Methods}

\section{Plant material and experimental conditions}

Tissue samples were harvested from commercial clonal trees of six years-old Eucalyptus grandis, kindly provided by Suzano Papel e Celulose. The field-trial was situated in Itapetininga city, State of São Paulo, Brazil $\left(23^{\circ} 35^{\prime}\right.$ $\left.20^{\prime \prime} \mathrm{S}, 48^{\circ} 03^{\prime} 11^{\prime \prime} \mathrm{W}\right)$ at an altitude of $656 \mathrm{~m}$. To analyze the changes in transcripts, proteins and metabolites during summer/active growth compared to winter/diminished growth, bark samples were harvested in January/ 2009 and July/2009 for summer and winter, respectively. Samples were harvested in the morning, between 9 and 10:00 am. The average temperature and precipitation during January/summer were $23.7{ }^{\circ} \mathrm{C}$ and $213.2 \mathrm{~mm}$, respectively. During the month of July/winter these parameters were $16.8{ }^{\circ} \mathrm{C}$ and $47.7 \mathrm{~mm}$, respectively. The bark of each tree was removed at chest height $(1.30 \mathrm{~m}$, exposing an area of approximately $20 \times 15 \mathrm{~cm}^{2}$ ). The cambial zone tissues in the inner surface of the bark were scraped with a razor blade and discarded, the bark samples were immediately frozen in liquid nitrogen. The field trial was a completely randomized design. Six bulked samples (10 trees each) were used as biological replicates. Three bulks represented summer and three represented winter trees. The plant material was used with the permission of Suzano Papel e Celulose S/A.

\section{RNA extraction and mRNA isolation}

Total RNA was extracted from bark samples using the protocol described by Zeng and Yang [57]. Total RNA concentration was measured spectrophotometrically at 260/ $280 \mathrm{~nm}$, in a U-3300 spectrophotometer (Hitachi, Tokyo, Japan). The absence of RNA degradation was verified by electrophoresis on a formamide-formaldehyde denaturing agarose gel $(1 \%)$. mRNA was isolated using Dynabeads ${ }^{\circ}$ mRNA purification kit (Invitrogen Dynal, Oslo, Norway), according to the manufacturer's instructions.

\section{Real-Time PCR}

Gene-specific primers were designed with Primer 3 software (Additional file 3: Table S1). Primer pairs were designed as follows: primer length between $18 \mathrm{pb}-25 \mathrm{bp}$, product length of $100-250 \mathrm{bp}$, melting temperatures $55-60{ }^{\circ} \mathrm{C}, \mathrm{GC} \%$ between 40 and $60 \%$. First and second strand cDNA synthesis were performed using the SuperScriptTM One-Step RT-PCR Platinum ${ }^{\circ}$ Taq (Invitrogen, Carlsbad, CA, USA) kit with RT/Platinum $^{\circ} \mathrm{Taq}$ (Invitrogen, Carlsbad, CA, USA) and using primers specific for the genes of interest (Additional file 3: Table S1). The cDNAs were produced in a Gene Amp PCR System 9700 thermocycler (Applied Biosystems, Foster City, CA, USA) using as annealing temperatures $57{ }^{\circ} \mathrm{C}$. The cDNAs $\left(10^{-1}\right)$ were used as a template for RT-qPCR assays, carried out in an iQ5 instrument (BioRad) to obtain de threshold quantification cycle $(C q)$ and the amplification efficiencies $(E)$. At the end of the PCR cycles, the thermocycler was programmed to perform a denaturation curve. The final volume of each reaction was $20 \mu \mathrm{L}$, including cDNA, $10 \mathrm{mM}$ of each primer and 1x Supermix SYBR Green real-time RT-PCR (Invitrogen). A negative control (no cDNA template) was included for every gene. Three biological replicates, each with three technical replicates, were analyzed. The calculation of relative expression ratios was carried out with the Relative Expression Software Tool (REST) [58] using the pairwise fixed reallocation randomization test for the statistical significance $(P \leq 0.05)$ [59]. Reference genes ( $\alpha$-tubulin and citoplasmatic malate dehydrogenase $(\mathrm{MDHc})$ ) were identified using NormFinder [60]. The software LinReg [61] was used to calculate the PCR efficiencies and the $\mathrm{C} q$ values of each gene analyzed.

\section{Proteomic analysis}

Total protein from bark was extracted by grinding the frozen tissue $(4 \mathrm{~g})$ and using the phenolic method according to Hurkman and Tanaka [62], with minor modifications described in Celedon et al. [35]. The tissues were homogenized in $15 \mathrm{~mL}$ of extraction buffer (0.7 M sucrose, 0.5 M Tris- $\mathrm{HCl}, \mathrm{pH}$ 7.5, $50 \mathrm{mM}$ EDTA, $0.1 \mathrm{M} \mathrm{KCl}, 1 \% \mathrm{w} / \mathrm{v}$ polyvinylpolypirrolidone (PVPP), $2 \% \mathrm{v} / \mathrm{v}$ 2-mercaptoethanol, and $2 \mathrm{mM} \mathrm{PMSF})$, by shaking for $30 \mathrm{~min}$ at $4{ }^{\circ} \mathrm{C}$. An equal volume of Tris$\mathrm{HCl}$ saturated phenol $\mathrm{pH} 8.5$ was added to the protein 
suspension. After an additional $30 \mathrm{~min}$ of shaking at $4{ }^{\circ} \mathrm{C}$, the phases were separated by centrifugation $(10,000 \times g$ for $30 \mathrm{~min}$ at $4{ }^{\circ} \mathrm{C}$ ). The phenol phase was recovered and re-extracted with an equal volume of extraction buffer. Proteins were precipitated from the phenol phase by adding 5 vol. of $0.1 \mathrm{M}$ ammonium acetate in methanol and incubated overnight at $-20{ }^{\circ} \mathrm{C}$. The samples were then centrifuged $\left(10,000 \times g, 30 \mathrm{~min}\right.$ at $\left.4{ }^{\circ} \mathrm{C}\right)$ and the resulting pellets were washed three times with $0.1 \mathrm{M}$ ammonium acetate in methanol, followed by a wash with acetone. The protein pellet was dried under vacuum at $4{ }^{\circ} \mathrm{C}$ and suspended in $1 \mathrm{~mL}$ of solubilization buffer $(7 \mathrm{M}$ urea, $2 \mathrm{M}$ thiourea, $0.4 \% \mathrm{v} / \mathrm{v}$ Triton X-100, $50 \mathrm{mM}$ dithiothreitol (DTT)). Proteins were quantified using the Bradford method [63]. Protein samples $(700 \mu \mathrm{g})$ were mixed with buffer $(340 \mu \mathrm{L})$ containing $10 \mathrm{mM}$ DTT, $4 \%(w / v)$ CHAPS, 1 \% IPG buffer (GE Healthcare, Chalfont St. Giles, UK). Bromophenol blue $(1 \% \mathrm{w} / \mathrm{v})$ was used to rehydrate for $12 \mathrm{~h}\left(20^{\circ} \mathrm{C}\right.$ and $\left.50 \mathrm{~V}\right)$ the strips of Immobiline IPG (18 cm -pH 4-7, linear gradient, GE Healthcare, Chalfont St. Giles, UK). Rehydrated strips were isoelectrofocused in an Ettan $^{\mathrm{Tm}}$ IPGphor $^{\mathrm{TI}}{ }^{\mathrm{m}}$ (GE Healthcare) for $1 \mathrm{~h}$, starting at $100 \mathrm{~V}$ and then $500 \mathrm{~V}$ for $1 \mathrm{~h}, 1000 \mathrm{~V}$ for $1 \mathrm{~h}$, $5000 \mathrm{~V}$ for $1 \mathrm{~h}$ and 8000 until reaching a total of $80,000 \mathrm{~V}$-h. Before the second dimension, strips were kept at room temperature for $15 \mathrm{~min}$ in equilibration buffer (6 $\mathrm{M}$ urea, $2 \% \mathrm{w} / \mathrm{v}$ SDS, $50 \mathrm{Mm}$ Tris- $\mathrm{HCl}, \mathrm{pH} 6.8$, $30 \% \mathrm{v} / \mathrm{v}$ glycerol) firstly with $1 \% \mathrm{w} / \mathrm{v}$ DTT and then with $2.5 \% \mathrm{w} / \mathrm{v}$ iodoacetamide (IAA) and $0.001 \%$ bromophenol blue. The second dimension was performed in $12 \%(\mathrm{w} / \mathrm{v})$ polyacrylamide gels, using a Protean II XI 2-D cell electrophoresis system (GE Helathcare), at $30 \mathrm{~mA}$ per gel until the dye reached the bottom of the gel. Three biological replicates were performed for each treatment. Proteins were detected using Coomassie Brilliant Blue G-250 [64]. Gels were incubated for $1 \mathrm{~h}$ in a solution containing $40 \%$ $(\mathrm{v} / \mathrm{v})$ ethanol and $10 \%(\mathrm{v} / \mathrm{v})$ acetic acid, in water. For protein detection the gels were left overnight in staining solution (20\% (v/v) methanol, $10 \%(\mathrm{w} / \mathrm{v})$ ammonium sulfate, $10 \% \mathrm{v} / \mathrm{v}$ phosphoric acid, and $0.1 \%(\mathrm{w} / \mathrm{v})$ Coomassie G-250). Gels were imaged using an Image scanner III and Labscan v 7.0 software (GE- Healthcare). Image analysis was performed automatically using the Image Master 2D Platinum software v 7.0 (GE Amersham Bioscience). Spots were detected using a smoothness of 8 , minimum area of 15 and a saliency of 40 , and spots across gels were matched using 5 landmarks per gel. Matching was performed automatically, and systematically confirmed after one-by-one visual checking: artefacts, or spots that could not be confidently validated as true matches, were disregarded and misalignments were corrected manually when appropriate. Spots were considered reproducible when well resolved in at least two of the three biological replicates. The normalized volumes (\% vol.) of the corresponding spots from summer and winter samples were compared to estimate differential expression of proteins during different seasons. To ensure the reproducibility between technical replicates, spots with coefficient of variation higher than $30 \%$ were excluded. To identify spots significantly expressed the data collected from protein spot volumes were subjected to Student's t-test $(P \leq 0,05)$ in Image Master v 7.0 software. In-gel digestion of proteins was performed as described in Celedon et al. [35] After, peptide mixtures were sequenced by online chromatography using a nano-Acquity UPLC (Waters") sistem coupled to a Q-TOF Ultima API mass spectrometer (Waters, UK). Mass spectrometer parameters were adjusted according Celedon et al. [35]. Ten microliters of sample were loaded onto a pre-column Symetry MCA C18 $5 \mathrm{~mm}$, $5630 \mathrm{~mm}$ (Waters) for sample pre-concentration and desalination, followed by peptide separation on an LC column Symmetry C185 mm, $32 \times 150 \mathrm{~mm}$ (Waters). Peptides were eluted using a linear gradient (10-45 \%) of solvent B (95\% (v/v) acetonitrile, $0.1 \%(\mathrm{v} / \mathrm{v})$ formic acid in water). The flow rate started with $5 \mathrm{~mL} / \mathrm{min}$ for the first $15 \mathrm{~min}$, then changing to $2 \mathrm{~mL} / \mathrm{min}$ for the next $25 \mathrm{~min}$, and back to $5 \mathrm{~mL} / \mathrm{min}$ in the last $5 \mathrm{~min}$. Solvent A consisted of $5 \% \mathrm{v} / \mathrm{v}$ acetonitrile, and $0.1 \% \mathrm{v} / \mathrm{v}$ formic acid in water. All analyses were performed using a positive ion mode at $3 \mathrm{kV}$ needle voltage. The mass range was set from 300 to 2000 $\mathrm{m} / \mathrm{z}$, and the MS/MS spectra were acquired for the most intense peaks having at least 15 counts.

\section{Protein identification/MSMS-data analysis}

The LC-MS/MS were processed using ProteinLynx v 2.0 (Waters) and Mascot Daemon (Matrix Science, Boston, MA) software, and the sequences searched against an in-house Eucalyptus database from Phytozome v1.1 (www.phytozome.net/eucalyptus.php) and NCBI. Combined MS-MS/MS search criteria used were as follows: trypsin digestion; fixed modification set as carbamidomethylation of cystein; variable modification set as methionine oxidation); mass accuracy of $50 \mathrm{ppm}$ for the parent ion and MS/MS mass tolerance of $0.1 \mathrm{Da}$. According to MASCOT probability analysis, only significant hits $(P \leq 0.05)$ were accepted. A match was considered significant if the peptide had a score higher than 70, based on Perkins et al. [65].

\section{Metabolic profiling}

Bark samples were ground into powder in liquid $\mathrm{N}_{2}$ and freeze-dried. Metabolites were extracted according to the method described by Hoffman et al. [66], with minor changes. Approximately $5 \mathrm{mg}$ of dried tissue was mixed with $1 \mathrm{~mL}$ of a chloroform-methanol-water mix (6:2:2) containing stable isotope reference compounds [15 $\mathrm{ng} \mathrm{mL}^{-1}$ each of $\left({ }^{13} \mathrm{C}_{3}\right)$-myristic acid, $\left({ }^{13} \mathrm{C}_{4}\right)$-hexadecanoic acid, $\left({ }^{2} \mathrm{H}_{4}\right)$-succinic acid, $\left({ }^{13} \mathrm{C}_{5},{ }^{15} \mathrm{~N}\right)$-glutamic 
acid, $\left({ }^{2} \mathrm{H}_{7}\right)$-cholesterol, $\left({ }^{13} \mathrm{C}_{5}\right)$-proline, $\left({ }^{13} \mathrm{C}_{4}\right)$-disodiumketoglutarate, $\left({ }^{13} \mathrm{C}_{12}\right)$-sucrose, $\left({ }^{2} \mathrm{H}_{4}\right)$-putrescine, $\left({ }^{2} \mathrm{H}_{6}\right)$-salicylic acid and $\left({ }^{13} \mathrm{C}_{6}\right)$-glucose). The metabolite extraction proceeded using a vibration mill set to a frequency of $30 \mathrm{~Hz} \mathrm{~s}^{-1}$ for $3 \mathrm{~min}$, with $3 \mathrm{~mm}$ tungsten carbide beads added to each extraction tube to increase the extraction efficiency. The extracts were then centrifuged for $10 \mathrm{~min}$ at $14,000 \mathrm{rpm}$ in an Eppendorf centrifuge (model 54178).

After, $100 \mathrm{~mL}$ of each supernatant was transferred to a GC-vial and evaporated to dryness. The samples were then derivatized with $30 \mu \mathrm{L}$ of methoxyamine hydrochloride $\left(15 \mathrm{mg} \mathrm{mL}^{-1}\right)$ in pyridine for $16 \mathrm{~h}$ at room temperature. Trimethylsilylation was performed by adding $30 \mu \mathrm{L}$ of N-methyl-N-(trimethylsilyl) trifluoroacetamide (MSTFA) with $1 \%$ TMCS to the samples and incubating them for $1 \mathrm{~h}$ at room temperature. After silylation, $30 \mu \mathrm{L}$ of heptane was added. Samples were analyzed, according to Gullberg et al. [67], using gas chromatography with time-of-flight mass spectrometry (GC/TOF-MS) together with blank control samples and a series of $n$-alkanes $(\mathrm{C} 12-\mathrm{C} 40)$, which allowed retention index to be calculated [68]. One microliter of each derivatized sample was injected in splitless mode by a CTC Combi Pal Xt Duo (CTC Analytics AG, Switzerland) auto-sampler in an Agilent 7890A gas chromatograph equipped with a $30 \mathrm{~m} \times 0.25 \mathrm{~mm}$ i.d. fused-silica capillary column with a chemically bonded $0.25-\mu \mathrm{m}$ DB 5 -MS UI stationary phase (J\&W Scientific, Folsom, CA). The injector temperature was $260{ }^{\circ} \mathrm{C}$, the septum purge flow rate was $20 \mathrm{~mL} \mathrm{~min}^{-1}$ and the purge was turned on after $75 \mathrm{~s}$. The gas flow rate through the column was $1 \mathrm{~mL} \mathrm{~min}$, the column temperature was held at $70{ }^{\circ} \mathrm{C}$ for $2 \mathrm{~min}$, then increased by $15{ }^{\circ} \mathrm{C} \mathrm{min}-1$ to $320{ }^{\circ} \mathrm{C}$, and held there for $4 \mathrm{~min}$. The column effluent was introduced into the ion source of a Pegasus HT time-of-flight mass spectrometer (Leco Corporation, St. Joseph, MI, USA). The transfer line and the ion source temperatures were 250 and $200{ }^{\circ} \mathrm{C}$, respectively. Ions were generated by a $70 \mathrm{eV}$ electron beam at an ionization current of $2.0 \mathrm{~mA}$, and 20-30 spectra $^{-1}$ (30 spectras $^{-1}$ run 1,20 spectra s$^{-1}$ run 2) were recorded in the mass range $50-800 \mathrm{~m} / \mathrm{z}$. The acceleration voltage was turned on after a solvent delay of $290 \mathrm{~s}$. The detector voltage was $1450-1490 \mathrm{~V}(1450 \mathrm{~V}$ run $1,1490 \mathrm{~V}$ run 2). All non-processed MS-files from the metabolic analysis were exported into ChromaTOF 2.12 software (Leco Corporation), in which all manual integrations and metabolite identification were done. All data treatment procedures (base-line correction and chromatogram alignment) were performed using customs scripts [68] in MATLAB. To compare the metabolite changes between summer and winter seasons the normalized data set (to tissue dry weight and internal standards) was Pareto scaled, log transformed and applied to multivariate and univariate analytical methods using the MetaboAnalyst software [69]. The supervised classification method PLSDA was carried out to discriminate between different groups (summer and winter). PLS-DA model fit was evaluated using the $\mathrm{R}^{2}$ and $\mathrm{Q}^{2}$ cross-validation performance measures [69], both of which vary between 0 and $1 . R^{2}$, the squared correlation coefficient between the dependent variable and the PLS-DA prediction, provides an indication of the "goodness of fit" (a value between zero and one, where one is a perfect correlation) from the model. $\mathrm{Q}^{2}$ provides an indication of "goodness-of-prediction" and is the averaged correlation coefficient between the dependent variable and the PLS-DA predictions. To identify the metabolites that contributed to the separation between the two groups we used the VIP from the PLS-DA model. VIP is a weighted sum of squares of the PLS loadings which indicates the importance of the variable to the whole model. Differential metabolites were selected based on PLS-DA model using a combination of VIP value $>1.0$ and $p$-value $(P \leq 0.05)$, by the univariate unpaired, two-tailed Student's t-test.

\section{Carbohydrate extraction and HPLC analysis}

Soluble sugars (glucose, sucrose and fructose) were extracted from bark samples. Tissues were grinded and freeze-dried for $48 \mathrm{~h}$, after $1 \mathrm{~mL}$ of water was added in $0.2 \mathrm{~g}$ of dry powder and samples were kept in bath $\left(80^{\circ} \mathrm{C}\right)$ for $1 \mathrm{~h}$. Then, samples were centrifuged for $10 \mathrm{~min}$ $16.000 \mathrm{~g}$, the supernatant was recovered and stored at $-4{ }^{\circ} \mathrm{C}$. Summer and winter samples were analyzed using a highperformance liquid chromatography (ICS 2500, HPLC Dionex) with amperometric detection (ED50) equipped with an autosampler, AS50. Sugars were assigned according to the retention times of standards (sucrose, glucose and fructose). A Carbopac PA-1 column $(4 \times 250 \mathrm{~mm}$, Dionex $)$ and a guard Carbopac PA-10 column $(4 \times 50 \mathrm{~mm}$, Dionex $)$ were used. To identify statistical differences between summer and winter samples a Tukey's test $(P \leq 0.05)$ was performed in SAS (SAS Institute, Cary, NC, USA).

\section{Additional files}

Additional file 1: Table S1. Primers used in real-time PCR analysis. (XLSX $11 \mathrm{~kb}$ )

Additional file 2: Figure S1. Representative 2-DE maps of E. grandis bark proteins. (A) Bark summer proteins map. (B) Bark winter proteins map. Arrows indicate differentially expressed spots. Three biological replicates were used for each season. (TIF 912 kb)

Additional file 3: Table S2. All metabolites identified in E. grandis bark. (XLSX 14 kb)

\section{Abbreviations}

2-DE, two-dimensional chain electrophoresis; $A D H 2$, alcohol dehydrogenase 2; ADH3, alcohol dehydrogenase 3; ATP, Adenosine triphosphate; CA,

carbonic anhydrase; Cq, threshold quantification cycle; ENO, enolase; FBAcl, fructose bisphosphate aldolase chloroplast; FBAcyt, fructose bisphosphate aldolase cytoplasmatic; GC-MS, gas chromatography mass spectrometry; GPI, 
glucose 6-phosphate isomerase; IDH, isocitrate dehydrogenase; NADP-ME, NADP Malic enzyme; PDC, pyruvate decarboxylase; PDH, pyruvate dehydrogenase; PEPC, phosphoenolpyruvate carboxylase; PFK, ATP-dependent phosphofructokinase; PFP, PPi-dependent phosphofructokinase; PGAM, phosphoglycerate mutase; PGK, phosphoglycerate kinase; PGM, phosphoglucomutase; PK, pyruvate kinase; PLS-DA, partial lest squares discriminant analysis; RbcL, rubisco large subunit; RbcS, Rubisco small subunit; RPI, ribose 5-phosphate isomerase; RT-qPCR, reverse transcription quantitative real time polymerase chain reaction; $\mathrm{SCL}$, succinyl-CoA ligase; SuSy1, sucrose synthase 1; SuSy3, sucrose synthase 3; TCA, tricarboxylic acid cycle; UDP, uridine diphosphate; UTP, uridine triphosphate; VIP, variable importance in the projection

\section{Acknowledgments}

We would like to thank Dr. Esteban Gonzalez (FuturaGene Corporation) for providing the biological material and José Mateus Wisniewski Gonsalves (FuturaGene) and Dr. Luis Felipe Boaretto for the help with the samples harvesting. We would like to thank FAPESP for the fellowship to J.S.M. (Proc. n 2011/01236-2).

\section{Funding}

This work was supported by the FAPESP (São Paulo Research Foundation) (Grant 2009/00808-2 and 2008/50361-1).

\section{Availability of data and materials}

The data sets supporting the results of this article are included within the article and its additional files.

\section{Authors' contributions}

IGF conceived of the study, carried out the experiments, analyzed the data and wrote the manuscript. DHM assisted in the RT-qPCR analysis and manuscript revision. JSM participate in the RT-qPCR and proteomic analysis. JB assisted in the carbohydrate extraction and HPLC analysis. PL and TM assisted with metabolomics studies. CAL conceived of the study, participated in its design and coordination, and reviewed the manuscript. All authors have read and approved the final manuscript.

\section{Competing interests}

The authors declare that they have no competing interests.

\section{Consent for publication}

Not applicable.

\section{Ethics approval and consent to participate}

Not applicable.

\section{Author details}

'Laboratório Max Feffer de Genética de Plantas, Departamento de Genética, Escola Superior de Agricultura Luiz de Queiroz, Universidade de São Paulo, Piracicaba, SP 13418-900, Brasil. ${ }^{2}$ Umeå Plant Science Centre, Department of Forest Genetics and Plant Physiology, Swedish University of Agricultural Sciences, Umeå SE-901 83, Sweden.

\section{Received: 1 December 2015 Accepted: 22 June 2016}

Published online: 01 July 2016

\section{References}

1. Brazilian Association of Planted Forest Producers (ABRAF): Annual report. Brazil. 2013. http://www.ipef.br/estatisticas/relatorios/anuario-ABRAF13-EN. pdf. Accessed 29 Jan 2014

2. Albaugh JM, Dye PJ, King JS. Eucalyptus and water use in souths Africa. Int J For Res. 2013:2013:1-11.

3. Lev-Yadun, Simcha: Bark - Encyclopedia of Life Sciences (ELS). Chichester, UK: John Wiley \& Sons; 2011.

4. Soler M, Serra O, Molinas M, Berthou EG, Caritat A, Figueras M. Seasonal variation in transcript abundance in cork tissue analyzed by real time RT-PCR. Tree Physiol. 2008;28:743-51.

5. Ogunwusi AA. Potentials of industrial utilization of bark. J Nat Sci Res. 2013; 3:106-15.

6. Pagter M, Sergeant K, Moller SM, Bertram HC. Changes in the proteome and water state in bark and xylem ofHydrangea paniculata during loss of freezing tolerance. Environ Exp Bot. 2013;106:99-111.
7. Lima MA, Lavorente GB, Silva HK, Bragatto J, Rezende CA, Bernardinelli OD, Azevedo ER, Gomez LD, McQueen-Mason SJ, Labate CA, Polikarpov I. Effects of pretreatment on morphology, chemical composition and enzymatic digestibility of eucalyptus bark: a potentially valuable source of fermentable sugars for biofuel production - part 1. Biotechnol Biof. 2013;6:75-92.

8. Kleczkowski LA. Glucose activation and metabolism through UDPglucose pyrophosphorylase in plants. Phytochemistry. 1994;37:1507-15.

9. Amor $Y$, Haigler $\mathrm{CH}$, Johnson S, Wainscott M, Delmer DP. A membraneassociated form of sucrose synthase and its potential role in synthesis of cellulose and callose in plants. Proc Natl Acad Sci. 1995;92:9353-7.

10. Haigler $\mathrm{CH}$, Ivanova-Datcheva M, Hogan PS, Salnikov W, Hwang S, Martin LK, Delmer DP. Carbon partitioning to cellulose synthesis. Plant Mol Biol. 2001:47:29-51.

11. Giuntoli B, Lee SC, Licausi F, Kosmacz M, Oosumi T, van Dongen JT, Bailey-Serres J, Perata P. A trihelix DNA binding protein counterbalances hypoxia-responsive transcriptional activation in Arabidopsis. PLoS Biol. 2014:12:e1001950.

12. Banti V, Giuntoli B, Gonzali S, Loreti E, Magneschi L, Novi G, Paparelli E, Parlanti S, Pucciariello C, Santaniello A, Perata P. Low oxygen response mechanisms in green organisms. Int J Mol Sci. 2013;14:4734-61.

13. Mithran M, Paparelli E, Novi G, Perata P, Loreti E. Analysis of the role of the pyruvate decarboxylase gene family in Arabidopsis thaliana under low oxygen conditions. Plant Biol. 2014;16:28-34.

14. Yang J, Kamdem DP, Keathley DE, Han KH. Seasonal changes in gene expression at the sapwood-heartwood transition zone of black locust (Robinia pseudoacacia) revealed by cDNA microarray analysis. Tree Physiol. 2004;24:461-74.

15. Kimmerer TW, Stringer MA. Alcohol dehydrogenase and ethanol in the stems of trees. Plant Physiol. 1988;87:693-7.

16. Harry DE, Kimmerer TW. Molecular genetics and physiology of alcohol dehydrogenase in woody plants. For Ecol Manage. 1991;43:251-72.

17. MacDonald RC, Kimmerer TW. Ethanol in the stems of trees. Physiol Plant. 1991;4:582-8

18. Nunes-Nesi A, Fernie AR, Stitt M. Metabolic and signaling aspects underpinning the regulation of plant carbon nitrogen interactions. Mol Plant. 2010;3:973-96.

19. Studart-Guimarães C, Fait A, Nunes-Nesi A, Carrari F, Usadel B, Fernie AR. Reduced expression of Succinyl CoA ligase can be compensated for by an upregulation of the $\gamma$-amino-butyrate (GABA) shunt in illuminated tomato leaves. Plant Physiol. 2007;3:626-339.

20. Cavalcanti JHF, Esteves-Ferreira AA, Quinhones CGS, Pereira-Lima IA, Nunes-Nesi A, Fernie AR, Araújo WL. Evolution and functional implications of the tricarboxylic acid cycle as revealed by Phylogenetic Analysis. Genome Biol Evol. 2014;10:2830-48.

21. Tegeder M, Weber A. Metabolite transporters in the control of plant primary metabolism. In: Control of primary metabolism in plants. Volume 1st ed. Oxford: Willey; 2006. p. 85-120.

22. Plaxton WC, Podestá FE. The functional organization and control of plant respiration. Crit Rev Plant Sci. 2006:25:159-98.

23. Berveiller D, Damesin C. Carbon assimilation by tree stems: potential involvement of phosphoenolpyruvate carboxylase. Trees. 2008;22:149-57.

24. Aschan G, Pfanz H. Non-foliar photosynthesis - a strategy of additional carbon acquisition. Flora. 2003:198:81-97.

25. Wittmann C, Pfanz H, Loreto F, Centritto M, Pietrini F, Alessio G. Stem CO2 release under illumination: corticular photosynthesis, photorespiration or inhibition of mitochondrial respiration? Plant Cell Environ. 2006;29:1149-58.

26. Martin W, Henze K, Kellerman J, Flechner A, Schnarrenberger C. Microsequencing and cDNA cloning of the Calvin cycle/OPPP enzyme ribose-S-phosphate isomerase (EC 5.3.1.6) from spinach chloroplasts. Plant Mol Biol. 1996:30:795-805

27. Pfanz H, Aschan G, Langenfeld-Heyser R, Wittmann C, Loose M. Ecology and ecophysiology of tree stems: corticular and wood photosynthesis. Naturwissenschaften. 2002;89:147-62.

28. Spreitzer RJ. Role of the small subunit in ribulose-1,5-bisphosphate carboxylase/oxygenase. Arch Biochem Biophis. 2003;2003:141-9.

29. Andersson I, Backlund A. Structure and Function of rubisco. Plant Physiol Bioch. 2008;2008:275-91.

30. Rison SC, Hodgman TC, Thornton JM. Comparison of functional annotation schemes for genomes. Funct Integr Genomics. 2000;1:56-69.

31. Carvalho MCCG, Gomes DGC, Carneiro RT, Moon DH, Salvatierra GR, Franceschin LM, De Andrade A, Celedon PAF, Oda S, Labate CA. SAGE 
transcript profiling of the juvenile cambial region of Eucalyptus grandis. Tree Physiol. 2008;28:905-18.

32. Kleczkowski LA, Geisler M, Ciereszko I, Johansson H. UDP-glucose pyrophosphorylase. An old protein with new tricks. Plant Physiol. 2004;134:912-8.

33. Winter $\mathrm{H}$, Huber SC. Regulation of sucrose metabolism in higher plants: Localization and regulation of activity of key enzymes. Crit Rev Biochem Mol Biol. 2000;35:253-89.

34. Labate MTV, Bertolo ALF, Nascimento DD, Gutmanis G, Andrade A, Rodrigues MJC, Camargo ELO, Boaretto LF, Moon DH, Bragatto J. Labate CA. Cloning and endogenous expression of a Eucalyptus grandis UDP-glucose dehydrogenase cDNA. Genet Mol Biol. 2010;33:686-95.

35. Celedon PA, De Andrade A, Meireles KG, Carvalho MCCG, Caldas DG, Moon DH, Carneiro RT, Franceschini LM, Oda S, Labate CA. Proteomic analysis of the cambial region in juvenile Eucalyptus grandis at three ages. Proteomic 2007;13:2258-74.

36. Renaut J, Hausman JF, Bassett C, Artlip T, Cauchie HM, Witters E, Wisniewski M. Quantitative proteomic analysis of short photoperiod and lowtemperature responses in bark tissues of peach (Prunus persica L. Batsch). Tree Genet Genomes. 2008:4:589-600.

37. Lippert D, Chowrira S, Ralph SR, Zhuang J, Aeschliman D, Ritland C, Ritland K, Bohlmann, J. Conifer defense against insects: Proteome analysis of Sitka spruce (Picea sitchensis) bark induced by mechanical wounding or feeding by white pine weevils (Pissodesstrobi). Proteomics. 2007;7:248-70.

38. Yin L, Tao Y, Zhao Z, Shao J, Li X, Liu G, Liu S, Zhu L. Proteomic and transcriptomic analysis of rice mature seed-derived callus differentiation. Proteomics. 2007;7:755-68.

39. Fernie AR, Stitt M. On the discordance of metabolomics with proteomics and transcriptomics: coping with increasing complexity in logic, chemistry and network interactions. Plant Physiol. 2012;158:1139-45.

40. Vogel C, Marcotte EM. Insights into the regulation of protein abundance from proteomic and transcriptomic analyses. Nat Rev Genet. 2012:13:227-32.

41. Feder ME, Hofmann GE. Heat-shock proteins, molecular chaperones, and the stress response: evolutionary and ecological physiology. Annu Rev Physiol. 1999;61:243-82.

42. Hundertmark M, Hincha DK. LEA (late embryogenesis abundant) proteins and their encoding genes in Arabidopsis thaliana. BMC Genomics. 2008:9:118-40.

43. Mittler R, Lam E, Shulaev V, Cohen M. Signals controlling the expression of cytosolic ascorbate peroxidase during pathogen-induced programmed cell death in tobacco. Plant Mol Biol. 1999;39:1025-35.

44. Roberts MR. 14-3-3 Proteins find new partners in plant cell signaling. Trends Plant Sci. 2003:8:218-23.

45. Chantuma P, Lacointe A, Kasemsap P, Thanisawanyangkura S, Gohet E, Clement A, Guilliot A, Ameglio T, Thaler P. Carbohydrate storage in wood and bark of rubber trees submitted to different level of $C$ demand induced by latex tapping. Tree Physiol. 2009;43:1-11.

46. Ashworth EN, Stirm VE, Volenec JJ. Seasonal variations in soluble sugars and starch within woody stems of Corms sericea L. Tree Physiol. 1993;13:379-88.

47. Caldeira MC, Fernandéz V, Tomé J, Pereira JS. Positive effect of drought on longicorn borer larval survival and growth on eucalyptus. Ann For Sci. 2002;59:99-106.

48. Epron $D$, Nouvellon $Y$, Ryan MG. Introduction to the invited issue on carbon allocation of trees and forests. Tree Physiol. 2012;32:639-43.

49. Bonhomme M, Peuch M, Ameglio T, Rageau R, Guilliot A, Decourteix M, Alves G, Sakr S, Lacointe A. Carbohydrate uptake from xylem vessels and its distribution among stem tissues and buds in walnut (Juglans regia L.). Tree Physiol. 2009;30:89-102.

50. Travert S, Valerio L, Fourasté I, Boudet AM, Teulieres C. Enrichment in specific soluble sugars of two eucalyptus cell-suspension cultures by Various treatments enhances their frost tolerance via a noncolligative mechanism. Plant Physiol. 1997;114:1333-442.

51. Herrmann KM, WEAVER LM. The shikimate pathway. Annu Rev Plant Physiol Plant Mol Biol. 1999;50:473-503.

52. Parson HT, Fry SC. Oxidation of dehydroascorbic acid and 2,3-diketogulonate under plant apoplastic conditions. Phytochemistry. 2011;75:41-9.

53. Fahnenstich $H$, Saigo M, Niessen M, Zanor MI, Andreo CS, Fernie AR, Drincovich MF, Flugge UI, Maurino VG. Alteration of organic acid metabolism in A. thaliana overexpressing the maize C4-NADPmalic enzyme causes accelerated senescence during extended darkness. Plant Physiol. 2007;145:640-52.
54. Hibberd JM, Quick P. Characteristics of $C_{4}$ photosynthesis in stems and petioles of $C_{3}$ flowering plants. Nature. 2002;415:451-4.

55. Pennycooke JC, Vepachedu R, Stushnoff C, Jones M. Expression of an alpha-galactosidase gene in petunia is upregulated during low-temperature deacclimation. J Am Soc Hortic Sci. 2004;129:491-6.

56. Luo ZB, Calfapietra C, Liberloo M, Scarascia-Mugnozza G, Polle A. Carbon partitioning to mobile and structural fractions in poplar wood under elevated CO2 (EUROFACE) and N fertilization. GCB Bioenergy. 2006;12:272-83.

57. Zeng $Y$, Yang $T$. Rna isolation from highly viscous samples rich in polyphenols and polysaccharides. Plant Mol Biol Rep. 2002;20:417-7.

58. Pfaffl MW, Horgan GW, Dempfle L. Relative expression software tool (REST) for group-wise comparison and statistical analysis of relative expression results in real-time PCR. Nucleic Acids Res. 2002;30:e36.

59. Pfaffl MW. A new mathematical model for relative quantification in real-time RT-PCR. Nucleic Acids Res. 2001;29:2003-7.

60. Andersen $C L$, Jensen JL, Orntoft TF. Normalization of real-time quantitative reverse transcription-pcr data: a model-based variance estimation approach to identify genes suited for normalization, applied to bladder and colon cancer data sets. Cancer Res. 2004;64:5245-50.

61. Ramakers C, Ruijtera JM, Depreza RHL, Moorman AFM. Assumption-free analysis of quantitative real-time polymerase chain reaction (PCR) data. Neurosci Lett. 2003;339:62-6.

62. Hurkman WJ, Tanaka CK. Solubilization of plant membrane proteins for analysis by two-dimensional gel electrophoresis. Plant Physiol. 1986;81:802-6.

63. Bradford MM. A rapid and sensitive method for the quantification of microgram quantities of protein utilizing the principle of protein-dye biding. Anal Biochem. 1976;72:248-54.

64. Candiano G, Bruschi M, Musante L, Santucci L, Ghiggeri GM, Carnemolla B, Orecchia P, Zardi L, Righetti, PG. Blue silver: a very sensitive colloidal Coomassie G-250 staining for proteome analysis. Electrophoresis. 2004;25:1327-33.

65. Perkins DN, Pappin DJ, Creasy DM, Cottrell JS. Probability-based protein identifications by searching sequence using mass spectrometry data. Electrophoresis. 1999;20:3551-67.

66. Hoffman DE, Jonsson P, Bylesjö M, Trygg J, Antti H, Eriksson ME, Moritz T. Changes in diurnal patterns within the Populus transcriptome and metabolome in response to photoperiod variation. Plant Cell Environ. 2010;23:1298-313.

67. Gullberg J, Jonsson P, Nordström A, Sjöström M, Moritz T. Design of experiments: an eficient strategy to identify factors inXuencing extraction and derivatization of Arabidopsis thaliana samples in metabolomic studies with gas chromatography/mass spectrometry. Anal Biochem. 2004;331:283-95.

68. Jonsson P, Johansson Al, Gullberg J, Trygg J, Grung B, Marklund S, Sjostrom $\mathrm{M}$, Antti $\mathrm{H}$, Moritz T. High-throughput data analysis for detecting and identifying differences between samples in GC/MS-based metabolomic analyses. Anal Chem. 2005;77:5635-42.

69. Xia J, Wishart DS. Web-based inference of biological patterns, functions and pathways from metabolomic data using MetaboAnalyst. Nat Protoc 2011;6:743-60.

\section{Submit your next manuscript to BioMed Central and we will help you at every step:}

- We accept pre-submission inquiries

- Our selector tool helps you to find the most relevant journal

- We provide round the clock customer support

- Convenient online submission

- Thorough peer review

- Inclusion in PubMed and all major indexing services

- Maximum visibility for your research

Submit your manuscript at www.biomedcentral.com/submit
Biomed Central 